\title{
Introduction Perspectives on Contemporary Home-based Work
}

\author{
Indrani Mazumdar
}

Approaches towards home-based work have seen significant shifts over the two decades preceding the adoption of the ILO Convention on Home Work (1996) and the more than two decades that followed. It was in this period that the situation of women home-based workers in "third world" countries came to the forefront. Their concerns were backed by women's movements in several countries, and became integrated with the gathering momentum of the permeable concept of informality in work relations in the informal sector and/or the informal economy, which continues to provide the typical frame for homebased work in contemporary times.

By the 1980s, home-based work had emerged as emblematic of the invisibility and lack of recognition of several forms of women's productive work, and of an expanding informal workforce. The conceptualization of home-based work in developing countries moved beyond the confines of self-employment in "traditional" or "household" industries to include piece-rated wage work, outsourced by modern industries to women in their homes. Following the ILO Convention, such industrial out-workers were globally designated as home workers, although the larger category of home-based workers continued to include the self-employed. ${ }^{1}$

From another vantage point, theorization around home workers was propelled by debates among feminists in developed capitalist countries regarding the nature and value of domestic labour (house work) as well as women's work for wages. Some argued that these debates did not take into account the "subsistence production" of women in the "third world". Carrying forward such questioning to third world locations, an influential study of export-oriented lace workers of Narsapur in India theorized that the introduction of capitalist farming led to "housewifization", followed by the integration of such

1 Indrani Mazumdar, Approach paper: Vulnerabilities of women home based workers. (New Delhi, 2005); Santosh K. Mehrotra and Mario Biggeri, 'A cross-country analysis of industrial outwork in Asia' in Mehrotra Santosh K. and Mario Biggeri, Asian Informal Workers: Global risks, local protection (Abingdon, 2007).

(C) INDRANI MAZUMDAR, 2022 | DOI:10.1163/9789004499614_018

This is an open access chapter distributed under the terms of the CC BY-NC-ND 4.o license. 
housewives into a world market-oriented production system. ${ }^{2}$ Underlying such analysis, of course, was the phenomenon of labour-intensive manufacturing that was being exported by corporate conglomerates of western countries to third world countries, which led to the conception of a new international division of labour (NIDL). But it was a combination of gender ideologies and export-oriented production that became increasingly central to approaches towards home-based work in developing countries.

Meanwhile historians of women's work and family life in industrializing Europe suggested that the reproductive strategies and family organization that influenced women's productive work or dependent situation had not been directly altered by industrialization and changes in the mode of production. ${ }^{3}$ Research on home-based work in the US pointed out that it was inevitably linked to the problems of working mothers; that its existence, and indeed persistence, denied the division between home and work, private and public. Evidence of the centrality of home-based work in the debates around state intervention in the labour contract and the gendering of such state action was added to the discussions. ${ }^{4}$ Across the world, feminists agreed that behind industrial home work lay the sexual division of labour that assigned child care and household maintenance to women, albeit redefined by capitalist industrialization that promoted ideologies of male breadwinner/worker, female housewife and homebound motherhood.

Such discussions remained largely outside the older institutionalized trade union frame that had premised itself on the waning of home-based work, and tended to have a more limited, and perhaps limiting, perspective on gender. Expanding numbers of women home-based workers actually emerged from "out of the shadows" through a combination of activism by organizations of informal women workers in the developing world (see for example Figure 15.1 depicting homebased worker members of such an organization of informal women workers in India); feminist debates around women's work in Europe, the US and "third world" countries; as well as a new strategic focus on women in government policy that developed around the UN's Decade for Women (1975-85). Further, as country after country restructured their economies towards neoliberal globalization, and as scholars, workers' organizations and

2 Maria Mies, 'Dynamics of Sexual Division of Labour and Capital Accumulation: Women Lace Workers of Narsapur, Economic and Political Weekly, 16:10/12 (1981), and Maria Mies, The Lace Makers of Narsapur: Indian Housewives Produce for the World Market (London, 1982).

3 Louise A Tilly and Joan W, Scott, Women, Work, and Family (New York, 1978).

4 Eileen Boris, Home to Work: Motherhood and the politics of industrial homework in the United States, (New York, 1994). 
women's movements grappled with increasingly integrated global markets and production systems, and complex informal labour relations, research on women home-based workers acquired particular salience.

From the 199os, as neoliberalism and globalization became more universal, theorization around global commodity chains (GCCs) and then global value chains (GVCs) became influential in discourses and methods of analysis of home-based work. Although rooted in world systems theories that had historically defined capitalism through trade and markets, the GCC approach redefined itself, on the premise that transnational corporations-driven internationalization of production in this period, and increasing integration in globalized coordination and governance - buyer or producer-driven, were qualitatively new. ${ }^{5}$ As GCC approaches combined with value-added chain analysis developed by business scholars, approaches towards home-based work began to focus even more on export orientation in home work in the developing world, or home work linked to global markets. Integration with international markets and globalization was seen by some as an opportunity for home workers to move from the margins to the centre stage, alongside a thesis that flexibilization of labour led to feminization. In the wake of the Asian financial crisis (1997) and its spill-over in Latin American countries, when "defeminization" began to be talked about, a reformulated view of informality that encompassed the range of "flexibilized" labour relations gained greater currency, with some commentators suggesting that women workers in export-oriented manufacturing were the early "winners" in the globalization process, but later began to lose out. ${ }^{6}$

At another level, developments in information technology, accelerated communications and fragmentation of production systems including of services were generating conditions for the development of home work in what was called the "new economy". From extravagant futuristic predictions of the death of industrialism and the rise of a new civilization where millions of jobs in factories and offices would be swept back into the home and its "living room" as an "electronic cottage", 7 through the actualities of the "digital revolution" with development of the internet, the submarine fibre-optic cable and the communications satellite in the 199os, and related expectations of IT-enabled home

5 Gary Gereffi, "Commodity Chains and Regional Divisions of Labor in East Asia", Journal of Asian Business, 12:1 (1996) pp. 75-112.

6 Marilyn Carr and Martha Chen, 'Globalization, Social Exclusion and Work: With Special Reference to Informal Employment and Gender', Working Paper no. 20, World Commission on the Social Dimension of Globalization, International Labour Office (Geneva, 2004).

7 Alvin Toffler, The third wave (New York, 1980). 


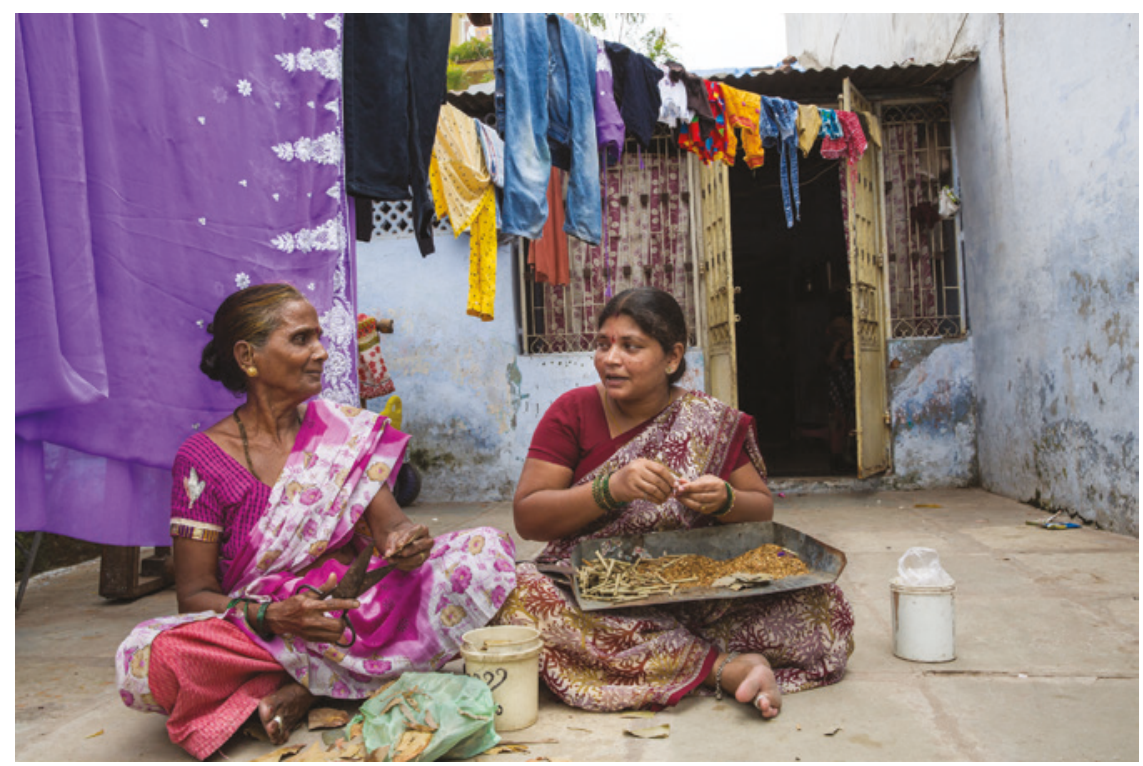

FIGURE 15.1 Ahmedabad, India: Rookmani Ram Naryan (left) and her daughter, Kavita Harshiresh Yemul, spend many hours each day on the floor of their small home hand rolling Indian-style cigarettes called bidi. Home-based workers such as Rookmani and Kavita, both members of the Self Employed Women's Association (SEWA), a trade union for poor, self-employed women in the informal sector, are vulnerable to exploitation by middlemen and suppliers. As sEWA members, they have more bargaining power and visibility for their hard-earned income.

PHOTO: PAULA BRONSTEIN/GETTY IMAGES REPORTAGE

work sweeping across the world, additional dimensions have indeed been brought into the discussions on home work.

From the perspective of a broader interest in home-based work in the contemporary age, the question is whether these new forms of home work are gender-indifferent, as conceived by Toffler; gender-friendly, as conceived by those who saw the developments as opening up more employment opportunities for women in developing countries; or reflective of a gendered construction of a low-wage, flexible reserve of home workers, to whom the risks of endemic volatilities inherent in the rising frequency of short booms followed by busts that characterized the era of untethered globalized finance could be transferred. For home workers' movements, the questions are more specific to the conditions of work and the possibilities of their regulation, and whether the new and more educated home-based workers in the digital service production economy can indeed relate to the poorer classes of home-based workers and vice versa. Bringing in research on some of the current processes at work in 
new and older forms of home-based work of the twenty-first century, the chapters in this section update, add fresh insights and indeed pose new challenges to the framing of issues and contexts of contemporary home-based work.

The section begins with Janine Berg's account of the conditions of homebased workers who are crowd-sourced through intermediary web-based platforms - a twenty-first-century form of digital home work. While sharing features akin to other home-based workers in terms of falling in the grey area between independence and dependency and invisibility, she points to differentiations among digital home-based workers by gradations in skills as well as nature of tasks and modes of payment. Specialized higher skilled professionals crowd-sourced by "macro-task" platforms are paid by project or by hours through a bargaining process. More clerical-type work from "micro-task" platforms, on the other hand, is paid for at rates set by clients or platforms without negotiation. The chapter draws on an ILO survey of 3,60o micro-task workers drawn from 75 countries in 2015 and 2017 by five leading digital platforms, to draw out the characteristics of the home-based worker. It points out that while work is searched for by, rather than reached to, home workers, intermediation is through an automated process with opaque systems of selection, rejection and constant rating by means of an algorithm. Workers' experiences and difficulties in contesting unfair practices, including wage theft, are discussed. Interestingly, Berg shows that significant amounts of unpaid labour time are expended by workers in the search and selection processes, as well as in work that may be rejected but are still used by employer/clients. The chapter brings out how a significant proportion of home workers receive payments below statutory minimum wages, and the common refrain of shortage of work availability. It presents the educational levels of workers, variations in gender composition across countries, and gender differences among those who combine home work with other jobs. It also suggests regulatory possibilities, using the same centralized data-based monitoring and surveillance technologies that are used for supervision of workers.

Archana Prasad's analysis of contemporary restructuring in internationalized garment production and its implications for home workers suggests that centralized accumulation, through increasing the share of unpaid labour time in production, has led to greater emphasis on sweatshop factories, where the flexibility associated with home work is achieved through the use of temporary workers in sweatshops, and where greater discipline and control over labour time is possible than in home work. Contesting suggestions that the bargaining power of home workers in global apparel value chains can be enhanced through skill augmentation, she argues that the contemporary reorganization in global apparel production is geared to discipline and social control of labour 
productivity in high-speed volume production that limits/marginalizes the use of home workers. Drawing on the findings of a survey of home-based workers by a trade union in India, Prasad shows that export-oriented home-based work for textiles and garments has only a small proportion of workers, with a more concentrated share only among embroidery workers. She suggests that while in an earlier phase, production for global markets indeed spawned home work in ready-made garments in India, at present it is domestic market-oriented production of ready-mades that is more significant, where the emphasis is on driving down costs in order to compete with the influx of low-priced international brands.

Srabani Maitra enters the field of contemporary home-based work from a different angle, through the increased share of the self-employed among homebased workers in Canada. Her study of South Asian immigrant "women entrepreneurs" shows how women from highly educated backgrounds were forced into home-based work as a consequence of gendered racism and exclusionary hiring in the Canadian labour market. Her findings are based on interviews with a range of women educated in their countries of origin - Pakistan, India, Bangladesh, Sri Lanka - who were selected as "qualified" immigrants based on criteria including education, work experience, age and language proficiency, with expectations of finding jobs suited to their qualifications. On their road to self-employment, she recounts stories of journeys through immigration processes, the search for jobs, and the final turn to home-based work in sewing, designing and stitching, and cooking, networking with kin and community in order to set up business and find markets for their products. Maitra reports that the women workers found satisfaction in creating and the appreciation they received for their products, and that they loved their work even though it involved long hours of laborious effort. She suggests that love, community ties and familial relations in the creation of relationships of mutual support can also be markers of entrepreneurial success, and that their small businesses should be included as part of the Canadian economy.

With reference to India, Sona Mitra argues that the current process of integration of women home-based workers into globalized production reflects a strategy of capital that focuses on taking advantage of locally created systems of home-based manufacture by women rather than generating it, and that home-based work has to be seen in the larger context of women's employment in manufacturing. Her analysis is located in the macroeconomic setting of slow rates of growth in manufacturing and overall employment, within the speculative finance-driven acceleration of India's growth rate since the 199os. Using national employment survey data, Mitra presents a subsectoral analysis of women's employment that shows a falling share of manufacturing, within 
which women were concentrated in traditional activities that catered mostly to domestic demand, and also in apparel, which is driven by a mix of both domestic and global demand with jewellery and some specific processed food products being solely export-driven. She concludes that domestic demand patterns influenced employment in rural home-based work in manufacturing, while urban home-based work was influenced by both local and global factors. She argues that home-based work in India was never exclusively driven by globalization. 